\title{
TRYB WYBORU RADNYCH W AMERYKAŃSKICH KORPORACJACH MUNICYPALNYCH
}

\section{WSTĘP}

Korporacje municypalne są podstawowym jednostkami samorządu terytorialnego tworzonymi, podobnie jak inne jednostki samorządowe, w drodze decyzji władz stanowych. Istotnym elementem różniącym jednak korporacje municypalne od jednostek szczebla wyższego, tj. hrabstw, jest decydująca rola mieszkańców w powołaniu jednostki municypalnej - to w drodze ich decyzji wszczyna się procedurę przekształcenia jednostki osadniczej w korporację mieszkańców. Oznacza to, że inaczej niż w państwach europejskich, terytorium Stanów Zjednoczonych nie jest w całości podzielone na podstawowe jednostki samorządowe. Gdzieniegdzie ich nie ma, a zarząd lokalny jest sprawowany przez władze samorządowego hrabstwa, zaś usługi są świadczone przez hrabstwo i/albo okręgi specjalne, tj. samorządy celowe. To pierwsza różnica, którą można wskazać między amerykańskimi korporacjami municypalnymi, a polskimi (czy europejskimi) gminami. Kolejna różnica wynika z faktu, że obok korporacji municypalnych występują na tym samy poziomie władz publicznych, lecz nie we wszystkich stanach, miasta i miasteczka. Różnią się one tradycją (są starsze od korporacji municypalnych) i instytucjami samorządowymi. W większości stanów, w których występują zarówno korporacje municypalne jak i miasta i miasteczka, te ostatnie na ogół realizują te same zadania co municypalitety. Nie mniej, fakt współwystępowania odmiennych jednostek organizacji terytorialnej o właściwości ogólnej jest również cechą szczególną samorządu amerykańskiego, która nie pozwala nam traktować korporacji municypalnych jako prostego odpowiednika europejskich gmin.

* Dr hab., profesor nadzw., Zakład Administracji Publicznej i Polityki Społecznej, Instytut Nauk o Polityce, Uniwersytet Rzeszowski, apawlowska@ur.edu.pl. 
W końcu trzecia, chociaż nie ostatnia, cecha korporacji municypalnych różniąca je od jednostek samorządowych szczebla podstawowego w Europie, to daleko posunięte zróżnicowanie związane z federalną formą państwa. Na Starym Kontynencie są wprawdzie państwa federalne, i - co do zasady - jednostki sfederalizowane (np. kraje związkowe w Republice Federalnej Niemiec, czy kantony szwajcarskie) mają swobodę w zakresie kształtowania struktury i instytucji samorządu terytorialnego $\mathrm{w}$ ich granicach, to jednak federalizm amerykański charakteryzuje się dalej idącą niezależnością stanów w tej kwestii. Dość wspomnieć, że Konstytucja Stanów Zjednoczonych w ogóle nie odnosi się do organizacji terytorialnej stanów, a zatem i do samorządu terytorialnego ${ }^{1}$. Natomiast zarówno ustawa zasadnicza Republiki Federalnej Niemiec z 1949 roku (w artykule 28), jak i Konstytucja Federalna Konfederacji Szwajcarskiej z 1999 roku (w artykule 51) zawierają gwarancje istnienia i autonomii gmin.

Daleko idąca niezależność władz stanowych w zakresie kształtowania ich organizacji terytorialnej oznacza - formalnie rzecz ujmując - istnienie 50 różnych systemów samorządu terytorialnego (51, jeżeli uwzględnić samorząd stolicy państwa - Waszyngton). Nie jest to bez znaczenia dla tematu niniejszej pracy, chociaż podkreślić należy, że w zakresie praw wyborczych stany i jednostki substanowe są zobligowane do przestrzegania przedmiotowych ustaw federalnych.

Celem autorki jest przedstawienie złożonego zagadnienia systemu wyborów radnych municypalnych $\mathrm{w}$ uproszczonej postaci, tj. zredukowania rozmaitości rozwiązań podyktowanej samodzielnością władz stanowych, ale również w pewnym zakresie społeczności lokalnych, do najczęściej spotykanych rozwiązań. Ważną przesłanką podjęcia tytułowego zagadnienia jest też charakterystyczna dla samorządów amerykańskich zależność ich instytucji od zmieniających się warunków społecznych i politycznych.

W pierwszej kolejności zostaną, w niezbędnym skrócie, opisane tradycje wyboru władz lokalnych, w szczególności te będące rezultatem ruchów reformistycznych przełomu XIX i XX wieku. Następnie wskazane zostaną źródła prawa wyborczego oraz kluczowe dla jego wykonywania zagadnienie równości głosów. W dalszej kolejności przedstawione zostaną modele wyboru radnych, których zasadniczym kryterium wyróżnienia jest podział terytorium jednostki samorządowej na okręgi wyborcze, lub też wybór radnych w jednym okręgu, który stanowi terytorium całej korporacji municypalnej. Kwestia ta została przeanalizowana $\mathrm{w}$ odniesieniu do wielkości jednostek samorządowych oraz modeli instytucjonalnych samorządu municypalnego. Krótko też zostało zarysowane zagadnienie formuły wyborczej.

${ }^{1}$ Kluczową regulacją pozwalającą na uznanie autonomii władz stanowych w tym zakresie jest X poprawka do Konstytucji federalnej: „Zakres władzy, który w niniejszej konstytucji nie został przekazany Stanom Zjednoczonym lub odebrany poszczególny stanom, pozostaje w ręku stanów lub narodu". Za: [Laidler 2007: 134]. 


\section{TRADYCJE WYBORÓW KOLEGIALNYCH ORGANÓW SAMORZĄDOWYCH}

Tradycje wyboru lokalnych ciał przedstawicielskich sięgają okresu kolonialnego. W owym czasie, ale również później - po ogłoszeniu Deklaracji Niepodległości - zakres czynnego prawa wyborczego był ograniczony do nielicznej populacji obywateli². Podobnie też ograniczony był zakres prawa biernego, które przysługiwało właścicielom (freeholder) lub obywatelom (freemen), którzy zamieszkiwali jednostkę osadniczą od co najmniej roku lub dwóch. Znaczenie w przyznawaniu praw wyborczych -w pierwszych dekadach istnienia kolonii, aczkolwiek nie we wszystkich koloniach - miała przynależność do Kościoła kongregacyjnego [Potz 2016: 209-210].

Pierwsze lata po uchwaleniu Deklaracji Niepodległości charakteryzowały się liberalizacją podejścia do prawa głosu w wyborach lokalnych. Jednak znaczny napływ ludności z obszarów wiejskich do miast skutkował przyjmowaniem przez ich władze bardziej zachowawczego stanowiska wobec upowszechnienia praw wyborczych, ograniczając je do tych, którzy płacili podatki lub dysponowali majątkiem o określonej wartości. Pierwszym stanem, który przyznał prawa wyborcze wszystkim dorosłym (którzy ukończyli 21 rok życia) i wolnym mężczyznom był Vermont (1791 r.). Do 1840 roku cenzus majątkowy i podatkowy w wyborach lokalnych znikł prawie całkowicie. Porzucono też powszechną w okresie kolonialnym praktykę dożywotniego wyboru radnych i uzupełniania składu rad w drodze kooptacji. Do absolutnych wyjątków należały statuty jednostek samorządowych, nadanych po 1775 roku, dopuszczające którąkolwiek z tych praktyk. Zamiast niej przyjęto zasadę wyboru radnych na kadencję trwającą od roku do trzech lat [Teaford 1975: 65-66; Adrian, Griffith 1976: 114; Lewicki 2010: 334].

Początkowo wybory odbywały się podczas zebrań otwartych, w głosowaniu jawnym (głosy oddawano viva voce), zwykłą większością głosów. Wybory nie opierały się na rywalizacji między kandydatami - przejawy opozycji uważano za zakłócenie porządku publicznego, a oponentów - za wichrzycieli³.

${ }^{2}$ Na przykład, w Zarządzeniach Podstawowych stanu Connecticut z 1639 r. występują obywatele i mieszkańcy, przy czym tylko ci pierwsi cieszyli pełnymi prawami wyborczymi. Według różnych szacunków dotyczących drugiej połowy XVII w., w jednostkach samorządowych tego stanu, obywatele stanowili - w zależności od jednostki samorządowej i od okresu historycznego - od 10\% do 80\% populacji dorosłych białych mężczyzn [Daniels 1979: 128; 1988: 63].

${ }^{3}$ Za takiego uznano Aleksandra Hamiltona, który w 1743 r. zdecydował się kandydować do Rady Miasta Annapolis (MD) przeciwko kandydatowi popieranemu przez gubernatora kolonii. Wystąpienie to wywołało manifestacje. Przestraszony burmistrz nakazał zamknięcie lokali wyborczych przed czasem i opieczętowanie urn. Wyborów ani nie kontynuowano, ani nie zakończono - ich wynik pozostał nierozstrzygnięty [Teaford 1975: 32-33]. 
Od 1801 roku, kiedy w Baltimore po raz pierwszy wykorzystano karty do głosowania (w trzy lata później - w Nowym Jorku), upowszechniło się głosowanie na piśmie. Początkowo karty do głosowania były czyste - wyborca sam wpisywał nazwisko preferowanego kandydata. Czasami już wypełnione karty do głosowania dostarczały partie polityczne. Ujednolicone karty do głosowania, przygotowywane przez instytucje rządowe (tzw. Australian ballot), pojawiły się po raz pierwszy w 1888 roku w Louisville (KY) [Adrian, Griffith 1976: 11-116; Lewicki 2010: 334; Adrian 1999: 49].

W okresie kolonialnym, ale również długo po uzyskaniu niepodległości, normalnym sposobem obsadzania stanowisk urzędniczych (tzw. szeregowych urzędników - row officers) były wybory. W jednostce samorządowej takich urzędników było od kilkunastu do kilkudziesięciu. Liczba urzędników lokalnych rosła, ale nie zmieniał się tryb ich powoływania, dlatego w XIX wieku listy wyborcze liczyły niekiedy ponad sto nazwisk (long ballot). Sytuacja ta, w połączeniu z pogłębiającym się zróżnicowaniem etnicznym i majątkowym, degradacją warunków życia w miastach, ale również demokratyzacją życia publicznego, która szczególnie silnie zaznaczyła się podczas prezydentury Andrew Jacksona (1829-1837), doprowadziły do wzrostu wpływów lokalnych machin partyjnych, które - głównie w dużych miastach - zdominowały lokalną politykę odwołując się także do korupcji wyborczej [Pawłowska 2011: 395-412].

Interesom machin partyjnych sprzyjały nie tylko warunki społeczne funkcjonowania samorządów, ale także sposób wyboru, a następnie wykonywania mandatu przez radnych miejskich. Ponieważ większe jednostki municypalne były dzielone na jedno-, czasami kilkumandatowe okręgi wyborcze, znaczenia nabrała rola radnych jako reprezentacji mieszkańców w poszczególnych okręgach. Zmniejszyła się natomiast ich rola jako mandatariuszy interesów całej korporacji municypalnej. Zatem pozycja ustrojowa rady wśród instytucji samorządowych malała, nabierała zaś znaczenia funkcja radnych jako adwokatów interesów okręgów wyborczych i ich łączników z machiną partyjną dysponującą zasobami (środki finansowe, wpływy w administracji publicznej, miejsca pracy) umożliwiającymi zaspokajanie potrzeb konkretnych wyborców [Teaford 1984: $17 \mathrm{i} \mathrm{n.].}$

Korupcjogenność i dysfunkcjonalność rozwiązań instytucjonalnych charakteryzujących samorządy ostatnich dekad XIX wieku były impulsem powstania ruchu społecznego zwanego Ruchem Postępowym (Progressive Movement). Jego działacze zmierzali do odsunięcia machin partyjnych od władzy, początkowo przez nadzorowanie procedury wyborczej i wystawianie własnych kandydatów. Rezultaty tych działań pozostawały jednak niezadawalające [Pawłowska 2016: $52 \mathrm{i} \mathrm{n}$.], dlatego sięgnięto po propozycje rozwiązań ustrojowych. Propozycje te dotyczyły reorganizacji instytucji samorządowych, ale także zmian w lokalnych ordynacjach wyborczych. 
Forma artykułu nie pozwala na szerokie omówienie reform instytucjonalnych początku XX wieku, krótka charakterystyka przyjętych wtedy rozwiązań jest jednak niezbędna. Tym bardziej że rozwiązania te przetrwały do dnia dzisiejszego, konstytuując podstawowe formy samorządu korporacji municypalnych.

Ostatnie dekady XIX wieku stoją pod znakiem wzmacniania pozycji burmistrza - wydłużona została jego kadencja, poszerzone kompetencje w zakresie powoływania urzędników samorządowych oraz wykonywania zadań korporacji municypalnych; coraz częściej był też on wyłaniany w wyborach bezpośrednich. Wzmocnienie organu wykonawczego i jego uniezależnienie od organu stanowiącego miało zmarginalizować wpływ (skorumpowanych) radnych na sprawy lokalne, w szczególności na świadczenie usług publicznych i ich nabywanie od podmiotów prywatnych.

Z upartyjnieniem samorządów walczono wprowadzając dwie nowe formy instytucjonalne. Jedną z nich był samorząd komisyjny, w którym organem stanowiącym jest kilkuosobowa komisja, zaś każdy z jej członków pełni funkcję wykonawczą w zakresie wskazanych zadań korporacji municypalnej. W drugiej formie zastąpiono ,polityczny” organ wykonawczy organem ,,administracyjnym", a właściwie menedżerskim, upodabniając - w pewnym sensie - korporacje municypalne do korporacji przemysłowych, gdzie decyzje rady (nadzorczej) są wykonywane przez menedżera - w jednostkach samorządu lokalnego - apolitycznego urzędnika zatrudnianego przez radę na podstawie kontraktu [Pawłowska 2016: $68 \mathrm{i}$.].

Podjęto też wysiłek zreformowania lokalnych ordynacji wyborczych. W 1909 roku została powołana Krajowa Organizacja Krótkich List Wyborczych (National Short Ballot Organization), zmierzająca do zastąpienia dotychczasowych list wyborczych zawierających kilkadziesiąt nazwisk kandydatów, listami krótkimi (short ballot), które pozwoliłyby obywatelom dokonywać świadomego i racjonalnego wyboru lokalnych przedstawicieli i urzędników. Wiązało się to również z ograniczeniem liczby radnych lokalnych (w przypadku samorządu komisyjnego i samorządu z menedżerem, rady były zaledwie kilkuosobowe), jak też stanowisk urzędniczych pochodzących z wyboru [Schiesl 1977: 172; Wheeland i in. 2014: 13S]. Zaczęto również rezygnować z podziału terytorium korporacji municypalnych na okręgi wyborcze przyjmując, że okręgiem wyborczym jest cały municypalitet (at-large elections) ${ }^{4}$. Preferencja dla wyboru

${ }^{4}$ Na przykład, w 1911 r. zmieniony został statut miasta Pittsburgh (PA): zredukowano liczbę radnych z 27 do 9 wybieranych z całego obszaru miasta (podobne zmiany przyjęto w Bostonie, Columbus, Detroit). Inne samorządy, chcące zreformować swój system reprezentacji, łączyły dotychczasowe okręgi wyborcze w większe jednostki, jednak nie obejmujące całego miasta; jeszcze inne decydowały się na przyjęcie wariantu mieszanego - wyboru części składu rady w mniejszych okręgach wyborczych, części zaś w całej jednostce samorządowej [Hays 1973: 149; Teaford 1993: 38]. 
radnych w skali całej jednostki samorządowej wynikała z oczekiwania, że tak wybrani radni nie będą się kierować interesem małej grupy mieszkańców, lecz brać pod uwagę dobro powszechne.

Popularność wyborów w skali całej jednostki municypalnej utrzymywała się(choć całkowicie nie przekreśliła praktyki wyboru w jednomandatowych okręgach wyborczych) aż do lat 70. XX wieku, kiedy ujawniła się jej ułomność w zakresie wyłaniania reprezentacji grup mniejszościowych, co będzie przedmiotem kolejnej części tego artykułu.

\section{OGÓLNE ZASADY WYBORU RADNYCH}

Tryb wyboru organów samorządowych podlega regulacjom konstytucji - federalnej i stanowych-oraz ustaw - federalnych i stanowych. Gwarancje równego prawa wyborczego zawarte są w poprawkach: XV, XIX, XXIV i XXVI do Konstytucji Stanów Zjednoczonych. Służy temu również wielokrotnie nowelizowana ustawa federalna o prawach wyborczych (Voting Rights Act) z 1965 roku.

Poprawka XV zabrania ograniczania i odbierania praw wyborczych ze względu na ,pochodzenie rasowe, kolor skóry lub poprzedni stosunek zależności służebnej" [Laidler 2007: 148]; poprawka XIX formułuje taki sam zakaz w odniesieniu do płci wyborcy, zaś poprawka XXIV - ze względu na niezapłacenie podatku wyborczego. Poprawka XXVI przyznaje czynne prawo wyborcze obywatelom, którzy ukończyli 18. rok życia. Wymóg wykazania się przez wyborcę umiejętnością czytania i pisania został zniesiony przepisami zawartymi w sekcji 2 ustawy z 1965 roku, zaś w sekcji 5. tej ustawy zakazano dokonywania zmian granic okręgów wyborczych, które mogłyby wpłynąć na wykonywanie praw wyborczych przez zamieszkujących je obywateli. Przepisy ustawy z 1965 roku odnosiły się tylko do wyborów prezydenckich i do Kongresu. Poprawki wprowadzone w 1970 roku poszerzały zakres przedmiotowy przepisów ustawy z 1965 roku o wybory organów władz publicznych wszystkich szczebli [Morgan 2004: 16-18; Laney 2008; Stevenson 2009: 161-163].

Próby ograniczania praw wyborczych były przedmiotem licznych orzeczeń sądowych, stąd też i one stanowią ważne źródło regulacji w interesującym nasz temacie. Szczególną uwagę sądy poświęcały manipulowaniu granicami okręgów wyborczych w celu uniemożliwienia oddania głosu i uzyskania reprezentacji w samorządowych organach kolegialnych przez mniejszości rasowe i etniczne, lub też naruszenia materialnej równości głosów, w celu ograniczenia wpływu tych grup społecznych na wynik wyborów ${ }^{5}$. Sądy orzekały

${ }^{5}$ Szerzej o orzecznictwie: Pawłowska [2016: 148-150]. Zagadnieniu równości materialnej głosów w odniesieniu do podziału na okręgi wyborcze zob. Pierzgalski, Stępień [2016: 7-29]. 
też w sprawach o zbyt szerokie określenie zakresu podmiotowego prawa wyborczego, tzn. przyznanie prawa głosu osobom, które czasowo przebywają na obszarze jednostki samorządowej (przez kilka miesięcy w roku, jak np. studenci lub emeryci). Taka praktyka była uważana za naruszenie zasady ,jeden człowiek, jeden głos", gdyż osoby te mogą głosować w wyborach lokalnych w dwóch jednostkach administracyjnych: w tej, którą zamieszkują na stałe i tej, w której przebywają czasowo. Rezydenci motywowali swoje pozwy obniżeniem wagi ich głosów w sytuacji gdy czynnym prawem wyborczym dysponują również nierezydenci. Zwykle jednak sądy uznawały takie umotywowanie skargi za niewystarczające i odrzucały zażalenia z tego tytułu [McCarthy Jr., Reynolds 2002: 158-159].

Tryb wyboru radnych jest przedmiotem regulacji ustaw stanowych, które określają uniwersalne i podstawowe zasady organizowania wyborów lokalnych, np. procedurę podziału terytorium jednostki samorządowej na okręgi wyborcze, wpisanie na listę wyborców, kalendarz wyborczy, warunki zgłaszania kandydatów, czas otwarcia lokali wyborczych, obowiązki administracji wyborczej, przebieg głosowania, termin i tryb ogłoszenia wyników wyborów itp. ${ }^{6}$ Regulacje te bywają dość ogólnikowe (kodeks wyborczy stanu Kalifornia), lub dość szczegółowe (kodeksy wyborcze stanów Arizona i Pensylwania ${ }^{7}$ ). To, czy wybory będą się odbywać w korporacji municypalnej jako jednym okręgu wyborczym, czy też zostanie ona podzielona na mniejsze okręgi wyborcze $^{8}$, liczba okręgów i liczba radnych, długość kadencji oraz ich dopuszczalna liczba, mogą być przedmiotem regulacji ustawowych albo statutowych ${ }^{9}$. Nie wdając się dość złożoną materię regulacji dotyczących przyjmowania statutu korporacji municypalnej zaznaczmy, że jego przepisy mogą być zdeterminowane ustawą stanową, może to też być tzw. statut władztwa miejscowego (home rule charter) przyjmowany przez mieszkańców w drodze referendum. Jednostki samorządowe mogą również działać wyłącznie na podstawie przepisów stanowych.

${ }^{6}$ Na przykładzie: Kodeksu wyborczego stanu Kalifornia 2016, http://law.justia.com/codes/ california/2016/code-elec/division-10/ (dostęp 18.03.2017).

72016 Arizona Revised Statutes. Title 16 - Elections and Electors; http://law.justia.com/ codes/arizona/2016/title-16/ (dostęp 18.03.2017). Pennsylvania Election Code, http://www.legis. state.pa.us/WU01/LI/LI/US/PDF/1937/0/0320 PDF (dostęp 18.03.2017).

${ }^{8}$ Patrz np.: VA Code $\S$ 24.2-304.1 (2016), http://law.justia.com/codes/virginia/2016/title-24.2/chapter-3/section-24.2-304.1/(dostęp 18.03.2017).

${ }_{9}$ Np. długość kadencji rad i liczba radnych w stanach Arizona i Pensylwania są przedmiotem regulacji ustawowych, podczas gdy w stanie Kalifornia są one uregulowane w statutach korporacji municypalnych, chyba że korporacja nie przyjęła statutu i funkcjonuje na podstawie prawa ogólnego, wtedy ustawa określa liczbę radnych na co najmniej 5. CA Govt Code $\S 36501$ (2016), http://law.justia.com/codes/california/2016/code-gov/title-4/division-3/part-1/ section-36501/ (dostęp 18.03.2017). 


\section{WYBORY RADNYCH W PRAKTYCE}

Wybory do rady korporacji municypalnej mogą odbywać się w jednym okręgu wyborczym, w którego granicach znajduje się cały obszar korporacji (at-large elections). Obszar ten może też zostać podzielony na mniejsze jednomandatowe okręgi wyborcze (ward elections) [Blair 1981: 176-177]. Samorządy lokalne starają się też łączyć zalety głosowania w mniejszych okręgach i w skali całej jednostki przyjmując rozwiązania mieszane. Jak już wspomniano, prawo stanowe pozostawia jednostkom samorządu terytorialnego znaczną swobodę w zakresie decyzji o podziale jednostki samorządowej na okręgi wyborcze, lub też braku takiego podziału. Występuje kilka wariantów rozwiązań w tej materii:

Wybory at-large, with no residency restrictions - korporacja municypalna stanowi jeden okręg wyborczy; kandydaci są umieszczani na jednej liście; wyborca oddaje tyle głosów ile jest miejsc w radzie; wybrani zostają ci kandydaci, którzy otrzymają kolejno najwięcej głosów aż do wyczerpania mandatów.

Wybory at-large, with seat, orposition, restrictions - korporacja municypalna stanowi jeden okręg wyborczy; kandydaci ubiegają się o konkretny mandat $\mathrm{w}$ radzie ${ }^{10}$; mieszkańcy oddają po jednym głosie na kandydatów ubiegających się o poszczególne mandaty, a więc mogą oddać tyle głosów ile jest mandatów.

Wybory at-large, with distric tresidency requirements for all seats - korporacja municypalna stanowi jeden okręg wyborczy, lecz dzieli się ją na mniejsze jednostki wyborcze; kandydaci muszą zamieszkiwać na terenie jednostek, którą reprezentują ${ }^{11}$; wyborcy oddają po jednym głosie na kandydatów rywalizujących w poszczególnych jednostkach, a zatem mogą oddać tyle głosów ile jest wybieranych radnych.

Wybory at-large, combination of district residency and positional seats - kombinacja wariantów 2. i 3.;

Partially mixed plan - wariant częściowo mieszany, w którym burmistrz, będący zarazem przewodniczącym rady, jest wybierany z obszaru całej korporacji, zaś radni w jednomandatowych okręgach wyborczych; wyborca oddaje dwa głosy (jeden na kandydata na burmistrza, drugi - na kandydata w okręgu wyborczym).

${ }^{10}$ Mandaty są oznaczone kolejnymi cyframi lub literami alfabetu, np. mandat \#1 lub A; mandat \# 2 lub B, itd. Kandydaci rywalizują ze sobą o uzyskanie konkretnego mandatu, np. kandydat a, kandydat b i kandydat c rywalizują o mandat \#1, zaś kandydaci d, e i f rywalizują o mandat \#2[MacManus, 1978: 169].

${ }^{11}$ Przykładowo, terytorium korporacji jest podzielone na jednostki: 1, 2, 3, 4 i 5 . O mandaty w jednostkach rywalizują: w okręgu 1 - kandydat a, kandydat b i kandydat c; w okręgu 2 - kandydaci d, e i f itd. 
Mixed plan - wariant mieszany, w którym część radnych jest wybieranych z całej jednostki samorządowej, zaś część w jednomandatowych okręgach wyborczych $^{12}$.

Single-memberdistrict plan - wybory w okręgach jednomandatowych; kandydaci muszą zamieszkiwać okręg wyborczy, w którym kandydują; wyborca może oddać jeden głos [MacManus 1978: 154-155].

Sposób wyboru radnych - w skali całej jednostki, lub w jednomandatowych okręgach wyborczych - zależy nie tylko od lokalnych warunków społecznych (poziom zróżnicowania etnicznego i/albo ekonomicznego mieszkańców). Wydaje się, że kluczowe znaczenie ma wielkość jednostki samorządowej oraz forma samorządu korporacji. Zależność tę starał się wykazać James Svara na podstawie danych zgromadzonych przez ICMA (International City/County Managers Association) (tab. 1).

Tabela 1. Sposób wyboru radnych a liczba mieszkańców oraz sposób wyboru radnych a forma samorządu lokalnego

\begin{tabular}{|c|c|c|c|c|c|c|c|}
\hline \multirow{3}{*}{ Sposób wyboru } & \multicolumn{4}{|c|}{ Liczba mieszkańców } & \multicolumn{3}{|c|}{ Forma samorządu } \\
\hline & \begin{tabular}{|c|} 
poniżej \\
2500
\end{tabular} & $\begin{array}{l}2500- \\
50000\end{array}$ & $\begin{array}{|cc|}50 & 000 \\
-250 & 000\end{array}$ & \begin{tabular}{|c|} 
ponad \\
250000
\end{tabular} & $\begin{array}{c}\text { Rada } \\
- \text { burmistrz }\end{array}$ & \begin{tabular}{|c|} 
Rada \\
- menedżer
\end{tabular} & Komisja \\
\hline & \multicolumn{7}{|c|}{ odsetek glosów } \\
\hline $\begin{array}{l}\text { W skali całej } \\
\text { jednostki } \\
\text { samorządowej }\end{array}$ & 84 & 65 & 53 & 7 & 54 & 70 & 75 \\
\hline Sposób mieszany & 4 & 17 & 36 & 52 & 21 & 17 & 6 \\
\hline $\begin{array}{c}\text { W okręgach } \\
\text { jednomandatowych }\end{array}$ & 12 & 18 & 11 & 41 & 26 & 13 & 19 \\
\hline
\end{tabular}

Źródło: opracowanie własne na podstawie Svara, Auer [2013: 28].

Tabela ilustruje odsetek korporacji municypalnych, w których praktykowany jest tryb wyboru radnych w skali całego municypalitetu, tryb mieszany i w okręgach jednomandatowych. Wyraźna jest zależność między liczbą mieszkańców a sposobem wyboru radnych. W większości korporacji liczących do 250000 mieszkańców radnych wybiera się at-large; korporacje liczące powyżej 250000 mieszkańców preferują ordynację mieszaną i wybory w okręgach jednomandatowych.

12 Jeżeli np. rada liczy sześciu członków - dwóch jest wybieranych z całej korporacji, zaś czterech w jednomandatowych okręgach wyborczych, wtedy wyborca dysponuje trzema głosami - dwa oddaje na kandydatów wybieranych z całej korporacji, zaś jeden - na kandydata z okręgu wyborczego, który zamieszkuje, [MacManus 1978: s. 169]. 
Wyborom at-large sprzyja forma samorządu z menedżerem jako organem wykonawczym, a także forma komisji ${ }^{13}$. Nieznacznie ponad połowa korporacji biorących udział w badaniu ICMA wybiera swoich radnych w jednym okręgu wyborczym obejmującym cały obszar jednostki; w $1 / 4$ wybory odbywają się w okręgach jednomandatowych; w pozostałych - w trybie mieszanym. Przyczyn popularności wyborów at-large wśród korporacji z menedżerem można poszukiwać w niskiej liczebności członków rady (zwykle pięciu), co minimalizuje ryzyko długich list wyborczych. Sposób mieszany wyboru radnych w korporacjach z menedżerem to zwykle wskazany powyżej wariant 5. wyborów. Zakładamy, że korporacje, gdzie organem wykonawczym jest burmistrz i które wybierają radnych at-large liczą stosunkowo niewielu mieszkańców ${ }^{14}$.

Ważny dla przebiegu i wyniku wyborów lokalnych jest ich partyjny/bezpartyjny charakter. W świetle badań przeprowadzonych w 2001 roku, w 77\% miast, liczących ponad 2500 mieszkańców, na kartach do głosowania służących wyborowi organów samorządowych nie zamieszczano informacji o przynależności partyjnej kandydata; zaś $80 \%$ radnych biorących udział w badaniu zostało wybranych w wyborach bezpartyjnych. Wielkość miasta nie ma znaczącego wpływu na upartyjnienie wyborów. Znaczenie wydaje się mieć natomiast ustrój organów samorządowych - w ponad $90 \%$ miast, w których organem wykonawczym jest menedżer wybór radnych ma charakter bezpartyjny. Wybory mają charakter bezpartyjny w $62 \%$ miast, gdzie organem wykonawczym jest burmistrz [Svara 2003: 14].

Powszechnie obowiązującą w Stanach Zjednoczonych jest ordynacja większościowa. W odniesieniu do jednostek samorządu terytorialnego, może obowiązywać zasada większości względnej albo bezwzględnej [MacManus 1996: 59-61]. Wymóg uzyskania przez kandydata większości bezwzględnej bywa związany z koniecznością przeprowadzenia głosowania w dwóch turach. $\mathrm{W}$ nielicznych przypadkach radnych wybiera się zgodnie $\mathrm{z}$ ordynacją proporcjonalną. Anna Dziduszko-Rościszewska podaje różne warianty jej wykorzystania $\mathrm{w}$ wyborach lokalnych ${ }^{15}$. Według pojedynczego głosu przechodniego są

${ }^{13}$ Biorąc pod uwagę, że forma komisji jest praktykowana w niespełna 2\% korporacji municypalnych, w całościowej ocenie zjawiska ma znaczenie marginalne.

${ }_{14}$ Warto nadmienić, że korporacje municypalne liczące powyżej 50 tys. mieszkańców stanowią zaledwie 3,6\% wszystkich korporacji, zaś korporacje liczące poniżej 1 tys. mieszkańców stanowią 47,1\%. Obliczenia własne na podstawie: Subcounty General-Purpose Governments by Population-Size Group: 2012, https://factfinder.census.gov/faces/tableservices/jsf/pages/productview.xhtml?src=bkmk (dostęp 19.03.2017).

${ }_{15}$ Dziduszko-Rościszewska [2015: 46-64].Wprowadzenie ordynacji proporcjonalnej było jednym z postulatów Ruchu Postępowego, zrealizowanym w nielicznych, chociaż dużych miastach, praktykowanym jednak dość krótko, np. w Cincinnati ordynacja proporcjonalna obowiązywała w latach 1924-1957; w Nowym Jorku w latach 1936-1949. W obu miastach radnych 
wybierani, od 1941 roku, radni miasta Cambridge (MA) ${ }^{16}$. W świetle danych FairVote, w maju 2015 roku jedna $\mathrm{z}$ form głosowania proporcjonalnego obowiązywała w wyborach radnych około 60 korporacji municypalnych ${ }^{17}$.

\section{ZAKOŃCZENIE}

W Stanach Zjednoczonych zwyczaj wyłaniania przedstawicieli społeczności lokalnych w wyborach bezpośrednich sięga okresu kolonialnego. W trybie wyboru obsadzano zresztą nie tylko stanowiska radnych, ale także licznych urzędników lokalnych. Przez pewien czas po ogłoszeniu Deklaracji Niepodległości, demokratyzacja życia publicznego była hamowana niechętnym stosunkiem włodarzy miejskich do osiedlających się w granicach miast przybyszów z obszarów wiejskich. Zmiany upowszechniające dostęp do urn wyborczych często spotykały się z działaniami ten dostęp ograniczającymi. W ocenie autorki, był to pierwszy raz, kiedy proces migracji ludności istotnie wpłynął na porządek wyborów lokalnych.

Po raz kolejny wpływ ten ujawnił się w ostatnich dekadach XIX wieku, kiedy machiny partyjne, napędzane degradacją warunków życia w rozwijających się - tym razem na skutek rosnącej imigracji - miastach przejęły władzę nad lokalną administracją. Pogłębiająca się dysfunkcjonalność struktur samorządowych, nie mogących sprostać piętrzącym się problemom społecznym, spotęgowana korupcją lokalnych notabli, spotkała się ze sprzeciwem grupy obywateli zaangażowanych w Ruchu Postępowym. Ruch ten zmierzał do usprawnienia samorządu terytorialnego reformując lokalne struktury władzy oraz uderzając $w$ więzi klientelistyczne łączące radnych $\mathrm{z}$ ich wyborcami. Zakwestionowany został dość powszechny w dużych miastach wybór radnych $\mathrm{w}$ jednomandatowych okręgach wyborczych. Proponowano, z jednej strony, zmniejszenie liczby radnych, z drugiej zaś - wybieranie ich w całej jednostce samorządowej jako jednym okręgu wyborczym. Wykorzystując ordynację wyborczą zmierzano więc do zmiany reprezentacji społeczności lokalnych w organach przedstawicielskich.

wybierano wedle systemu pojedynczego głosu przechodniego. Dzięki wykorzystaniu ordynacji proporcjonalnej w obu miastach skład rady zyskał na reprezentatywności - w Cincinnati reprezentację w Radzie Miasta uzyskali Afroamerykanie, w Nowym Jorku - republikanie (w Radzie tradycyjnie zdominowanej przez demokratów), a z czasem również Amerykańska Partia Pracy, liberałowie, a nawet komuniści [Banfield, Wilson 1963: 96-97; Adrian 1999: s. 50].

${ }^{16}$ City of Cambridge Municipal Elections, http://www.cambridgema.gov/ /media/ BD029816F80C4CDC89FD22B40EEBE4BE.ashx (dostęp 19.03.2017).

${ }^{17}$ Obliczenia własne na podstawie: Jurisdictions Using Fair Representation Voting, http://www. fairvote.org/jurisdictions_using_fair_rep\#full_list_of_fair_voting jurisdictions (dostęp 19.03.2017). 
Rozwiązania instytucjonalne zgłaszane i implementowane na przełomie XIX i XX w. nie sprzyjały równouprawnieniu Amerykanów przy urnach wyborczych, co ze szczególną siłą ujawniło się w latach 60 . XX wieku. Wybory at-large skutkowały brakiem reprezentacji grup rasowych i etnicznych w lokalnych organach przedstawicielskich. Stąd zwrot w kierunku okręgów jednomandatowych, a także ordynacji mieszanych. Praktyczność i większa reprezentatywność wyborów w okręgach jednomandatowych, względnie wedle ordynacji mieszanej jest widoczna w przypadku korporacji municypalnych liczących ponad 250 tys. mieszkańców. Im mniej mieszkańców liczy jednostka samorządowa, tym większe prawdopodobieństwo wyboru radnych at-large. Takim wyborom sprzyja również forma samorządu z menedżerem oraz komisja. Obecność burmistrza jako organu wykonawczego wprawdzie w ponad połowie korporacji łączy się z wyborami radnych at-large, ale w licznych przypadkach wybory te odbywają się w okręgach jednomandatowych lub zarówno w okręgach jednomandatowych, jak i w skali całej jednostki samorządowej.

Fatalnym skutkom zaangażowania partii politycznych w sprawy lokalne należy też przypisać dość powszechną zasadę bezpartyjności elekcji municypalnych, którą ugruntowało zarządcze podejście do rozwiązywania problemów lokalnych, co uosabia menedżer miasta.

Pomimo wysiłków organizacji pozarządowych nie udało się przekonać amerykańskich wyborców do ordynacji proporcjonalnej. Zwyczaj głosowania w okręgach jednomandatowych i wybór większością względną członków organów kolegialnych na wszystkich poziomach władz publicznych jest utrwalony zwyczajem, którego zmiana - w dającej się przewidzieć przyszłości - nie znajdzie wystarczającego poparcia społecznego.

\section{BIBLIOGRAFIA}

Adrian Charles R. 1999. Forms of Local Government in American History. W Roger L. Kemp (ed.), Forms of Local Government. A Handbook on City, County and Regional Options. Jefferson: McFarland \& Co. Inc. Publishers.

Adrian Charles R., Griffith Ernest S. 1976. The History of American City Government. The Formation of Traditions, 1775-1870. New York: Praeger.

Banfield Edward C., Wilson James Q. 1963. City Politics. Cambridge: Harvard University Press $\&$ the MIT Press.

Blair George S. 1981. Government at the Grass-Roots. Pacific Palisades: Palisades Publishers Daniels Bruce C. 1979. The Connecticut Town. Growth and Development, 1635-1790. Middletown: Wesleyan University Press.

Daniels Bruce C. 1988. The Fragmentation of New England. Comparative Perspectives on Economic, Political, and Social Divisions in the Eighteenth Century. New York-Westport-London: Greenwood Press. 
Dziduszko-Rościszewska Anna. 2015. „Projekty reform amerykańskiego system wyborczego na szczeblu federalnym, stanowym i lokalnym". Athenaeum. Polskie Studia Politologiczne 45.

Hays Samuel P. 1973. The Politics of Reform in Municipal Government in the Progressive Era. W Blaine A. Brownell, Warren E. Stickle (eds.), Bosses and Reformers. Urban Politics in America, 1880-1920. Boston: Houghton Mifflin Co.

Laney Garrine P. 2008.CRS Report for Congress. The Voting Rights Act of 1965, As Amended: Its History and Current Issues. Congressional Research Service.

Lewicki Zbigniew. 2010. Historia cywilizacji amerykańskiej. Era sprzeczności1787-1865. Warszawa: Wydawnictwo Naukowe Scholar.

MacManus Susan A. 1978. „City Council Election Procedures and Minority Representation: Are They Related?". Social Science Quarterly 11.

MacManus Susan A. 1996. County Boards, Partisanship, and Elections. W Donald. C. Menzel (ed.), The American County. Frontiers of Knowledge. Tuscaloosa and London: The University of Alabama Press.

McCarthy Jr. David J. Reynolds Laurie. 2002. Local Government Law. In a Nutshell. St. Paul: Thomson/West.

Morgan R.P. 2004. Governance by Decree. The Impact of the Voting Rights Act in Dallas. Lawrence: University Press of Kansas.

Pawłowska Agnieszka. 2011. Burmistrz i boss - instytucjonalne i społeczne źródła przywództwa w miastach amerykańskich. W Wawrzyniec Konarski, Agnieszka Durska, Szymon Bachrynowski (red.), Kryzys przywództwa we współczesnej polityce. Warszawa: Wydawnictwo SWPS ,Academica”.

Pawłowska Agnieszka. 2016. Samorzad terytorialny w Stanach Zjednoczonych Ameryki. Warszawa: Wydawnictwo Naukowe Scholar.

Pierzgalski Michał., Stępień Paweł. 2016. „Instytucjonalne uwarunkowania procedury zmiany granic okręgów wyborczych w Stanach Zjednoczonych”. Studia Wyborcze 22.

Potz Maciej. 2016. Teokracje amerykańskie. Źródła i mechanizmy władzy usankcjonowanej religijnie. Łódź: Wydawnictwo Uniwersytetu Łódzkiego.

Schiesl Martin J. 1977. The Politics of Efficiency. Municipal Administration and Reform in America 1800-1920. Berkeley: University of California Press.

Stevenson Sandra M. 2009. Understanding Local Government. San Francisco: LexisNexis.

Svara James H., Auer Jennifer C. 2013. „Perspectives on Changes in City Government Structure". The Municipal Year Book. ICMA.

Svara James H. 2003. Two Decades of Continuity and Change in American City Councils. Washington, DC: National League of Cities.

Teaford Jon C. 1975. The Municipal Revolution In America. Origins of Modern Urban Government, 1650-1825. Chicago and London: The University of Chicago Press.

Teaford Jon C. 1993.The Twentieth Century American City. Baltimore-London: The Johns Hopkins University Press.

Teaford Jon C. 1984. The Unheralded Triumph. City Government in America, 1870-1900, Baltimore-London: The Johns Hopkins University Press.

Wheeland Craig R., Kelleher Palus Christine., Wood Curtis. 2014. „A Century of Municipal Reform in the United States: A Legacy of Success, Adaptation, and the Impulse to Improve". American Review of Public Administration 4 [suppl.]. 


\section{STRESZCZENIE}

W artykule przedstawiono system wyborów radnych municypalnych. Opisano tradycje wyboru władz lokalnych, w szczególności te, będące rezultatem ruchów reformistycznych przełomu XIX i XX wieku. Następnie wskazano źródła prawa wyborczego oraz kluczowe dla jego wykonywania zagadnienie równości głosów, a także modele wyboru radnych, których zasadniczym kryterium wyróżnienia jest podział terytorium jednostki samorządowej na okręgi wyborcze, lub też wybór radnych w jednym okręgu, który stanowi terytorium całej korporacji municypalnej. Kwestia ta została przeanalizowana w odniesieniu do wielkości jednostek samorządowych oraz modeli instytucjonalnych samorządu municypalnego. Krótko też zostało zarysowane zagadnienie formuly wyborczej.

Słowa kluczowe: korporacja municypalna, Stany Zjednoczone, radni, wybory, samorząd lokalny.

\section{THE MODE OF SELECTING COUNCILORS IN US MUNICIPAL CORPORATIONS (summary)}

The paper examines the complex issue of the municipal councilor selections in the United States. The traditions of local elections, in particular reforms resulting from the Progressive Movement in the turn of the $19^{\text {th }}$ and $20^{\text {th }}$ centuries, is briefly presented. The legal basis of the voting rights and electoral rules are studied. Types of council member election procedures are examined. At-large and ward elections are presented in relation to the size of municipal corporations and the form of their government.

Keywords: municipal corporation, United States, councilors, elections, local government. 